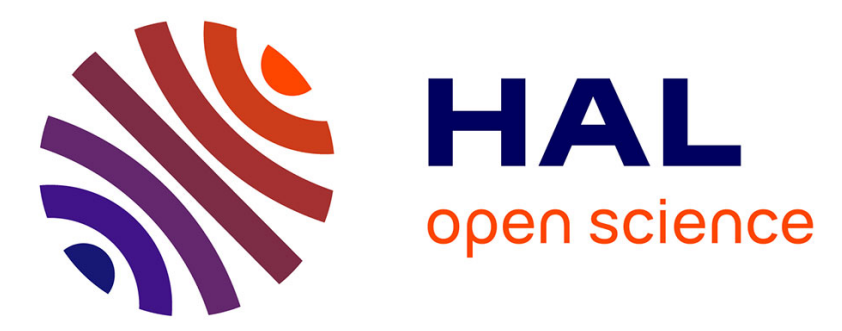

\title{
Monoterpene source emissions from Chamonix in the Alpine Valleys
}

Aurélie Rouvière, Guillaume Brulfert, Patrick Baussand, Jean-Pierre Chollet

\section{To cite this version:}

Aurélie Rouvière, Guillaume Brulfert, Patrick Baussand, Jean-Pierre Chollet. Monoterpene source emissions from Chamonix in the Alpine Valleys. Atmospheric environment, 2006, 40 (19), pp.36133620. 10.1016/j.atmosenv.2005.09.058 . hal-00202916

\section{HAL Id: hal-00202916 https://hal.science/hal-00202916}

Submitted on 11 Feb 2020

HAL is a multi-disciplinary open access archive for the deposit and dissemination of scientific research documents, whether they are published or not. The documents may come from teaching and research institutions in France or abroad, or from public or private research centers.
L'archive ouverte pluridisciplinaire HAL, est destinée au dépôt et à la diffusion de documents scientifiques de niveau recherche, publiés ou non, émanant des établissements d'enseignement et de recherche français ou étrangers, des laboratoires publics ou privés. 


\title{
Monoterpene source emissions from Chamonix in the Alpine Valleys
}

\author{
Aurélie Rouvière $^{\mathrm{a}, *}$, Guillaume Brulfert ${ }^{\mathrm{b}}$, Patrick Baussand ${ }^{\mathrm{a}}$, Jean-Pierre Chollet $^{\mathrm{b}}$ \\ ${ }^{a}$ Groupe de Recherche sur l'Environnement et la Chimie Atmosphérique, Laboratoire de l'université Joseph Fourier (Grenoble 1), \\ 39, boulevard Gambetta, 38000 Grenoble, France \\ ${ }^{\mathrm{b}}$ Laboratory of Geophysical and Industrial Fluid Flows (University J. Fourier, INP Grenoble, CNRS), BP53, 38041 Grenoble cedex, France
}

\begin{abstract}
Measurements of volatile organic compounds (VOCs) and in particular biogenic VOCs were taken near Chamonix, in the alpine valleys within the framework of the POVA program (Alpine Valley Pollution). The general topics of the program were the comparative studies of air quality in the Chamonix and Maurienne valleys (France) and the modelling of atmospheric chemistry. The main objective is to characterize the pollution sources and study the relationship between atmospheric dynamics and pollution events. To do this, it was necessary to take into account all quantifiable and localizable sources. Measurements of VOCs showed an abnormally high quantity of monoterpene concentrations (around $10 \%$ in mass of the total VOC concentrations). Isoprene and monoterpenes produced mainly by vegetation are among the most abundant natural VOCs, but these measurements were carried out in winter and during this season biogenic emissions are weak. The aim of this present work is to determine and understand this phenomenon. Domestic heating, generally not taken into account in studies of outdoor air, had a considerable impact on terpene concentrations in the valley.
\end{abstract}

Keywords: Monoterpenes; Heating; Modelling; Wood combustion; Alpine valley

\section{Introduction}

Alpine valleys are sensitive to air pollution due to the location of emission sources, topography (narrow valley surrounded by high ridges) and local meteorology (temperature inversions and slope winds). Studies of volatile organic compounds (VOCs) at polluted sites in mountains and forests

\footnotetext{
*Corresponding author. Tel.: + 3340456520294 ; fax: +3340456520295 .

E-mail address: Aurelie.Rouviere@ujf-grenoble.fr (A. Rouvière).
}

have been carried out for several years (Goldan et al., 1995; Ciccioli et al., 1993; Pio and Valente, 1998). Such situations are rarely investigated with specific research programs taking into account detailed gas atmospheric chemistry. Several studies on the influence of atmospheric dynamics over complex terrain on air quality have been carried out with several field campaigns in the Alpine area over the last two decades; e.g. POLLUMET (Lehning et al., 1996), MAP (http://www.map.ethz.ch/), VOTALP I (Wotawa and Kromp-Kolb, 2000) and VOTALP II (http://www.boku.ac.at/imp/votalp/ votalpII.pdf). 
As a result of the accident in the Mont Blanc tunnel on 24 March 1999, international traffic between France and Italy was stopped through the Chamonix valley (France). The heavyduty traffic (about 2130 trucks per day) was transferred to the Maurienne valley, with up to 4250 trucks per day passing through. The general objectives of the POVA program are the comparative studies of air quality in these two French alpine valleys before and after the reopening of the tunnel to heavyduty traffic, and the characterization of emission sources and dispersion of pollutants. The program includes several field campaigns, including three-dimensional modelling, in order to study the impact of traffic on air quality and to identify local development scenarios.

VOCs are emitted in substantial quantities from both anthropogenic and biogenic sources (Guenther et al., 1995; Olivier et al., 1996). The production and emission of biogenic VOCs from vegetation have been recognized since the early 1960s (Went, 1960). Biogenic emissions of VOCs account for more than $90 \%$ of the global emissions (Guenther et al., 1995) and forests are the main source of biogenic emission. VOCs can have a major influence on the chemistry of the lower atmosphere. It is well established that the phase degradation of VOCs plays a central role in the generation of a variety of secondary pollutants (Atkinson, 2000; Jenkin and Clemitshaw, 2000), which have a harmful impact on human health and on the environment.
In this work, we will focus mainly on the study of terpenes from Chamonix in the alpine valley. The analysis covers the measured VOC distribution in Chamonix. It also includes information about terpene concentrations, determination of monoterpene sources and finally a comparison between measurement and modelling. A modelling system developed for the program using $300-\mathrm{m}$ grid cells to calculate the dynamics and reactive chemistry makes it possible to accurately define the chemical reactions on a small scale. Thus, modelling allows to access VOC concentrations and distribution of emission sources in the total concentration.

\section{Sampling procedure and analytical conditions}

\subsection{Sampling sites}

The field campaign took place from 15 to 22 January 2003 in the Chamonix valley. This valley is $23 \mathrm{~km}$ long, closed at the lower end by a narrow pass (La Cluse) and at the upper side by le Col des Montets (1464 m a.s.1.) towards Switzerland (Fig. 1). The general orientation of the valley is close to SW-NE. With a Northern latitude of $45.92^{\circ}$ and an Eastern longitude of $6.87^{\circ}$, the center of the area is approximately $200 \mathrm{~km}$ from Lyon (France), $80 \mathrm{~km}$ from Geneva (Switzerland) and $100 \mathrm{~km}$ from Turin (Italy). The valley is rather narrow $(1-2 \mathrm{~km}$ on the floor) and $5 \mathrm{~km}$ from ridge to ridge. The valley floor lies on average at $1000 \mathrm{~m}$ a.s.1. The altitude of the
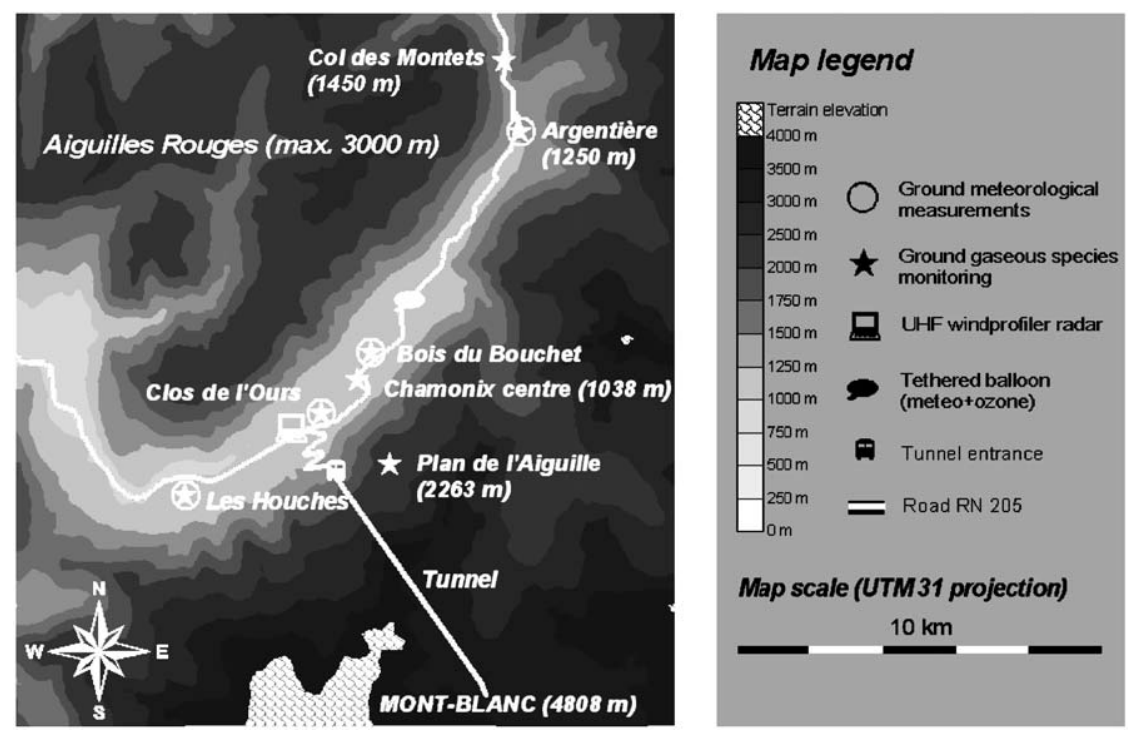

Fig. 1. Topography of the Chamonix valley: main measurement site valley center: latitude $45.92^{\circ} \mathrm{N}$, longitude $6.87^{\circ} \mathrm{E}$. 
highest mountain (Mont Blanc) is $4810 \mathrm{~m}$ a.s.l. Vegetation is relatively dense with many grassland and forest areas $\left(131 \mathrm{~km}^{2}\right.$ : grassland, $198 \mathrm{~km}^{2}$ : coniferous forests and $29 \mathrm{~km}^{2}$ : broadleaf forests for an $858 \mathrm{~km}^{2}$ global area).

Chamonix is the principal town of this valley with 10,000 permanent inhabitants, excluding the many tourists. The main anthropogenic sources of emissions are vehicle traffic, residential heating (mostly burning fuel and wood) and a limited number of agricultural activities. There is only one main road supporting all of the traffic in and out of the valley, but many secondary roads are spread over the valley floor and on the lower slopes. During the closure of the Mont Blanc tunnel to Italy, the traffic at the entrance of the valley $(14,400$ vehicles per day on average) was mostly composed of cars $(91 \%$ including $50 \%$ diesel powered), with a low number of local trucks $(5 \%)$ and tourist vehicles $(1 \%)$. Natural sources of emission are limited to forested areas, with mainly coniferous species ( $95 \%$ of spruce, larch and fir). Different VOCs and pollutants were measured: alkanes, aromatics, terpenes, chlorinated compounds, oxide of nitrogen (NO) and ozone $\left(\mathrm{O}_{3}\right)$. The results presented here relate to Chamonix Mont Blanc, an urban site of $1038 \mathrm{~m}$ a.s.l located in a residential area of the Chamonix town $\left(6.87^{\circ} \mathrm{E} ; 45.92^{\circ} \mathrm{N}\right)$, in an open grassy area about $50 \mathrm{~m}$ from a secondary street. The temperature observed on this site ranged from -6 to $+6{ }^{\circ} \mathrm{C}$ with an average of $-0.5^{\circ} \mathrm{C}$.

\subsection{Sampling methods}

VOC measurements were performed using TENAX cartridges with the Smart Automatic Sample System (SASS). The SASS was created via a collaboration between the TERA-Environment and GRECA laboratories. The sample appliance traps VOCs on TENAX cartridges using different flow rates. It can be used for intensive one-off or ongoing campaigns and for standard samples using an atmospheric simulation chamber. Each sampling is $30 \mathrm{~min}$ long at a flow rate of $100 \mathrm{~mL} \mathrm{~min}^{-1}$ corresponding to a $3 \mathrm{~L}$ air sample. 84 sampled were collected from each site during 7 days, every 2 hours during 30 minutes. When a sampling is finished, the cartridge is closed and conserved at low temperature.

\subsection{Analytical methods}

All samples were analyzed by an automatic thermodesorption device designed by Perkin Elmer connected to a gas chromatograph coupled with a mass spectrometer (GC/MS). Analytes were separated with a $50 \mathrm{~m} \times 0.25 \mathrm{~mm}$ fused silica column with a $1 \mu \mathrm{m}$ PM-5MS stationary phase, flushed with

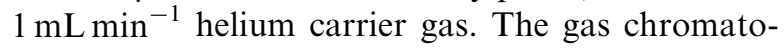
graphy temperature program was as follows: the initial oven temperature was $50^{\circ} \mathrm{C}$ and was then raised to $250{ }^{\circ} \mathrm{C}$ at a rate of $5^{\circ} \mathrm{Cmin}^{-1}$, and maintained for $5 \mathrm{~min}$. VOC identification using the mass spectrometer was carried out using retention times, standard compounds and a GC/MS library. Full-scan mode was used with a mass range from 35 to 350 and a scan speed of $0.5 \mathrm{scan} \mathrm{s}^{-1}$. The quantification was determined using the specific ions of the compounds studied. Calibration curves were obtained for all compounds using standard samples prepared in an atmospheric simulation chamber in the laboratory. The atmospheres were generated in a $200 \mathrm{~L}$ glass chamber by introducing a known quantity of pure organic compounds into the vacuum chamber. Then, the chamber was filled with purified and dried air to atmospheric pressure. Standard samples were realized using TENAX cartridges with the SASS.

\section{Results and discussion}

\subsection{VOC concentrations}

The VOCs identified during the field campaign were aromatics, alkanes, terpenes and chlorinated compounds. The concentrations were in the ppbv range for each in all measurements. Aromatic compounds and alkanes were in majority $(39 \%$ and $35 \%$, respectively) followed by terpenes (9\%) in the Chamonix urban station (Fig. 2). These VOCs were derived from anthropogenic compounds, i.e. primary pollutants arising mainly from vehicular transport. This result is expected in winter, when emissions of biogenic origin are weak (Hakola et al., 2003; Kim et al., 2005). However, there was also an important proportion of terpenes. The lack of biogenic sources in winter cannot explain such concentrations. The aim of the present paper is to determine the terpene sources.

\subsection{Terpene concentrations}

The terpenes identified and quantified during this field measurement for Chamonix site were $\alpha$-pinene, $\beta$-pinene, limonene and isoprene which is a hemiterpene. Many authors have already quantified 
terpenes in various rural and urban sites (Staudt et al., 1997; Ciccioli et al., 1993; Pio and Valente, 1998). Comparison of values with our case (Table 1) shows that terpene concentrations for Chamonix were specific.

It was found that the monoterpene concentrations were higher. Generally isoprene $\left(\mathrm{C}_{5} \mathrm{H}_{8}\right)$ and terpenes (such as $\alpha$-pinene) are the most common hydrocarbons released from vegetation, escaping from the stomata. But measurements were taken in winter and during this time the vegetation gives off few terpenes. Moreover, in winter, photochemistry is weak and temperatures are low. Temperature inversions and local weather phenomena frequently lead to the accumulation of emitted anthropogenic and biogenic airborne species in the low layers of the atmosphere (Anquetin et al., 1999).

Fig. 3 shows that terpenes are correlated with temperature: the lower the temperature, the greater the terpene concentration. The other VOCs do not depend on temperature. So, there exists a source of terpenes specifically related to cold weather conditions. Although the lifetimes of monoterpenes are

\section{Chamonix}

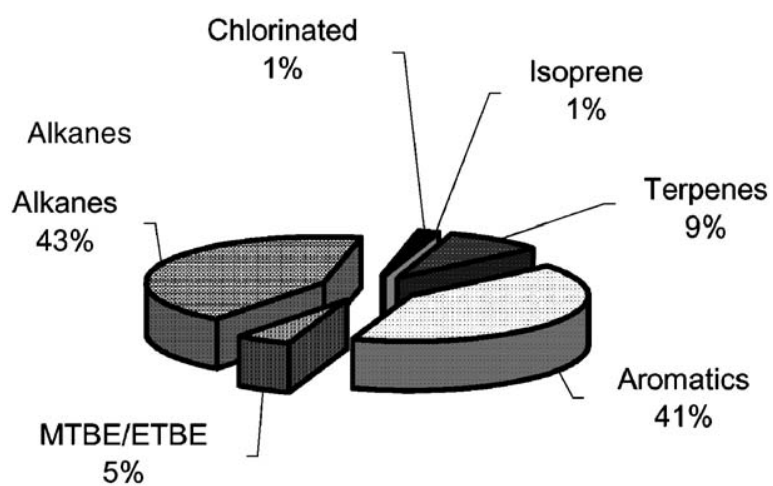

Fig. 2. VOC distribution ( $\%$ in mass of VOC total emissions) for the Chamonix measurement site, from 15 January 2003 to 22 January 2003. longer in winter than in summer, there is clearly a source of monoterpenes, different from biogenic sources during winter, that explains the concentration levels and the temperature-terpene correlation.

\subsection{Characterization of terpenes source}

Determination of VOC origin in valleys is especially challenging. VOCs such as aromatic compounds and alkanes can be emitted by many sources. The most significant are automobile gases, hydrocarbon combustion, biomass combustion, coal combustion, gasoline evaporation, paint, solvents, polymer combustion and wood transformation
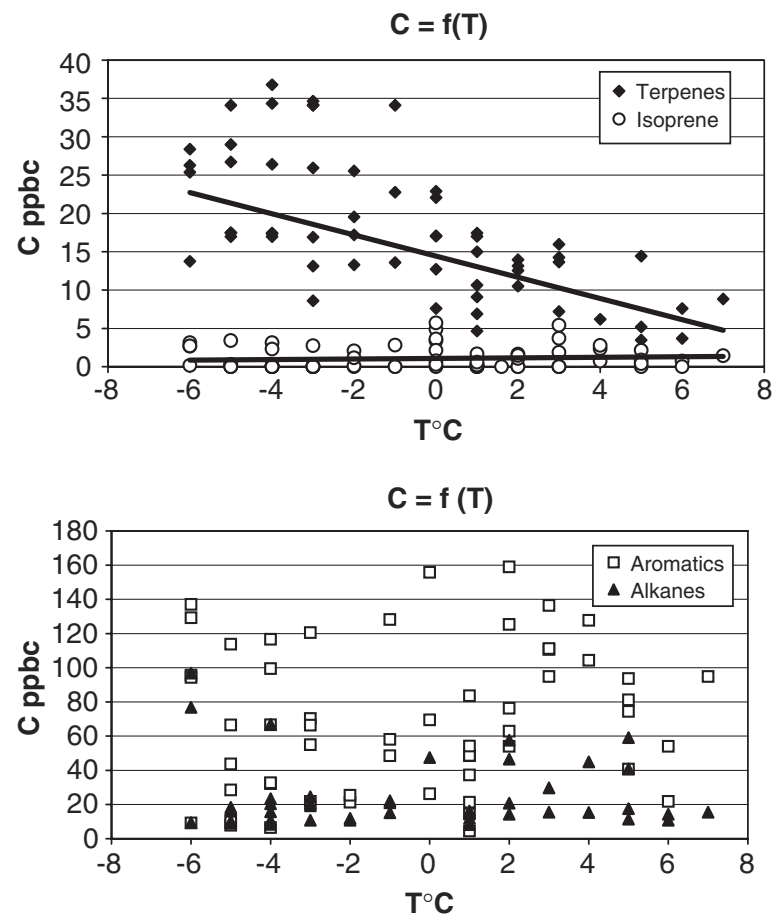

Fig. 3. Correlation between temperature and VOC concentrations for the Chamonix measurement site from 15 January 2003 to 22 January 2003: terpenes, isoprene (top) and aromatics, alkanes (bottom).

Table 1

Monoterpene concentrations (ppbv) for different sites

\begin{tabular}{lllllll}
\hline & $\alpha$-Pinene & $\beta$-Pinene & Limonene & Site & Date & Sources \\
\hline Grenoble & 0.006 & 0.002 & 0.014 & Urban & 2002 & Colomb (2002) \\
Los angeles & 0.28 & - & - & Urban & September 1993 & Fraser et al. (2000) \\
Alabama & 0.69 & 0.40 & 0.69 & Rural & 1990 & Goldan et al. (1995) \\
Storkow & 1.53 & 0.29 & 0.06 & Rural & 1993 & Ciccioli et al. (1993) \\
Chamonix & 0.26 & 0.17 & 1.29 & Urban & January 2003 & Rouviere et al. (2004)
\end{tabular}


processes. The influence of the road traffic in the alpine valley has already been established (Prévôt et al., 2000). Moreover, benzene, toluene, ethylbenzene and xylenes are present mainly in fuel oils and solvents (Fontaine, 2000) and alkanes are often associated with pollution from diesel engines (Schauer et al., 2002). Nevertheless, there are other sources of emission to consider.

In winter wood combustion becomes important. However, there are little data concerning compounds related to wood combustion, in particular on the specification of VOCs in fumes. Moreover, these studies are rather difficult to extrapolate from because of the types of wood burnt, the moisture level, age and the presence of oxygen at the time of combustion. Some publications cover this subject. Lobert et al. (1991) studied the phenomenon of biomass burning and calculated the quantity of VOCs thus emitted per year, whereas Schauer et al. (2001) studied the combustion of pine. In the Chamonix valley the majority of vegetation is composed of coniferous trees. Therefore in order to observe whether heating has an impact on the concentration of pollutants, an analysis of pine wood fumes was carried out (Fig. 4). The results showed the presence of aromatics (benzene, toluene, xylenes), alkanes (heptane, octane, nonane) and terpenes (isoprene, limonene, $\alpha$-pinene).

In the preceding paragraph, only terpenes were correlated with temperature. However, according to Fig. 4, aromatics, alkanes and isoprene are emitted by wood combustion and are also emitted by other important sources. So, the emission of these other sources is higher than for wood combustion. This is why these compounds do not depend on temperature (Fig. 3). Isoprene, a hemiterpene that is also present in gasoline, does not depend on temperature. Biogenic emissions in winter are very low; this experiment made it possible to highlight that the combustion of wood is a source of terpene emission into the atmosphere.

\subsection{Measurement and modelling tools}

Comparisons between measured VOC concentrations and results from mesoscale modelling have been made by Rouvière et al. (2004). A system of models developed to account for the chemical

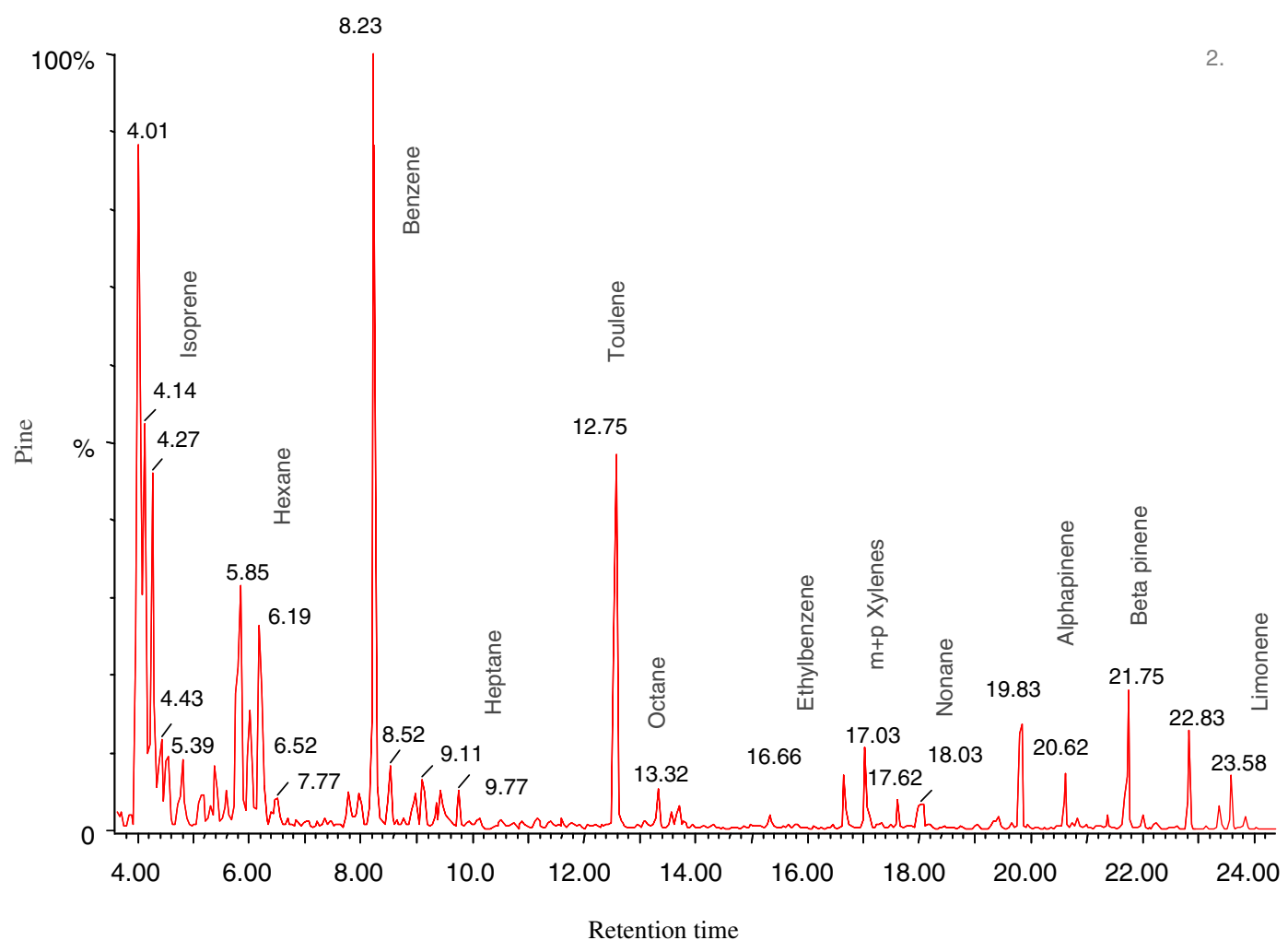

Fig. 4. Analysis of fumes emitted by pine combustion. 
dynamics in Alpine valleys is described in detail in Brulfert et al. (2005a). This modelling tool is based on a hierarchy of atmospheric and chemistry models using several grid-nesting levels. The valley was gridded horizontally at spacings of $300 \mathrm{~m} \times 300 \mathrm{~m}$. This grid encompassed a domain of about $25 \mathrm{~km} \times 25 \mathrm{~km}$. Available meteorological and chemical measurements such as $\mathrm{O}_{3}$ and $\mathrm{NO}_{x}$ were used to evaluate the model results (Brulfert et al., 2005a). The methodology and the emission factors for the VOC inventory model are basically identical to those developed for the Maurienne valley inventory (Brulfert et al., 2005b). VOC concentrations from TAPOM are in good agreement with measurements using this $300-\mathrm{m}$ horizontal resolution.

The spatial distribution of the total emissions of NMVOC is presented in Fig. 5 where the main point sources can be located. Emissions are concentrated in the bottom of the valley. The distribution of emissions presented in Fig. 6 shows a majority of anthropogenic emissions of NMVOC for the period $(58 \%)$.
Chemical models not only provide $\mathrm{O}_{3}$ and $\mathrm{NO}_{x}$ concentration fields but they can also access VOC concentrations. Thus, in order to validate the assumption of heating as a terpene source, the model takes into account different parameters like the presence or absence of traffic, heating and regional emissions (existence of sources were realized one by one and compared with a scenario without only background pollution and the "real" computation with all the sources and the background pollution). The results obtained from the model (Figure 7) show that road traffic accounts for approximately $40 \%$ VOC emission sources and that heating (including wood combustion) is significant at approximately $20 \%$.

\section{Conclusion}

The work carried out within the framework of the POVA program provides a series of results which can be used in different models. The qualitative and quantitative knowledge of such emissions is essential

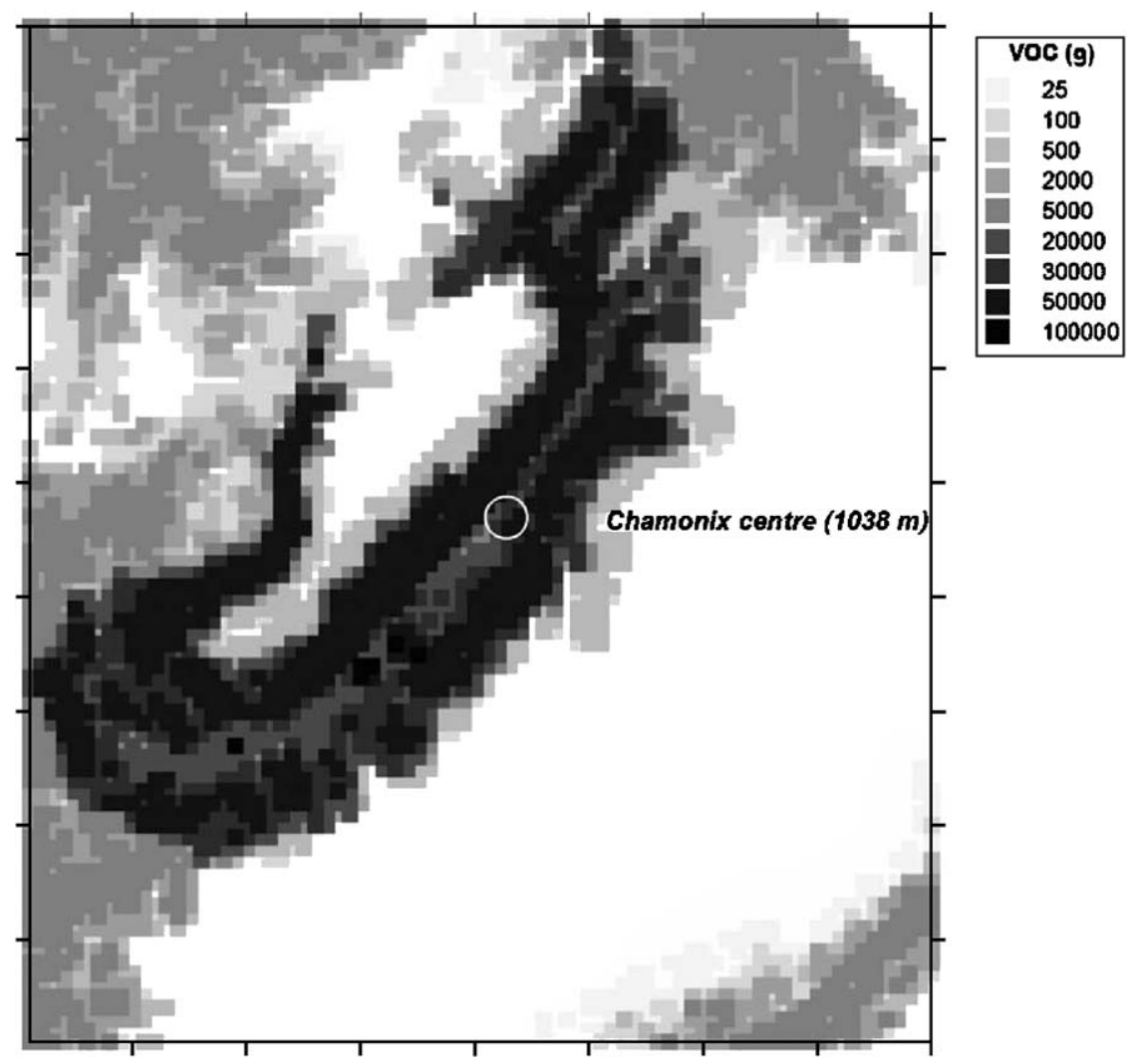

Fig. 5. Spatial distribution of atmospheric emissions of NMVOC in the Chamonix valley, from 15 January 2003 to 22 January 2003 . The white circle indicates the location of the measurement site in the Chamonix center.

UTM32 ED50 coordinates are $(324190 ; 5076431)$ for the top left-hand corner and $(349090 ; 5104331)$ for the bottom right-hand corner. 


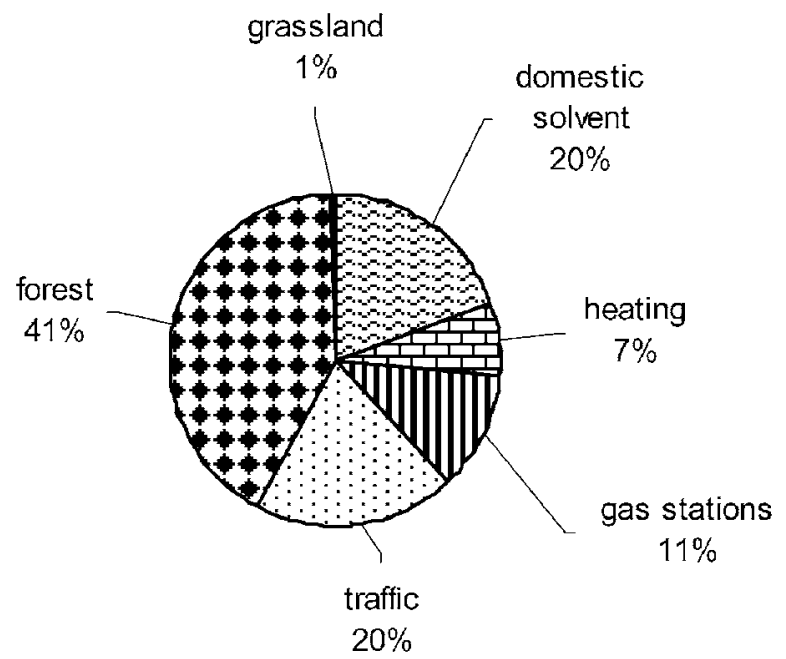

Fig. 6. Distribution of non-methane volatile organic compounds emissions for the whole Chamonix valley, from 15 January 2003 to 22 January 2003. The total emissions of NMVOC for this period are 8,84 tons.

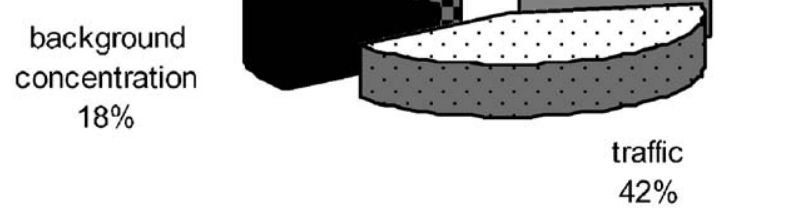

Fig. 7. Results from modelling: distribution of VOC emission sources for the Chamonix measurement site, from 15 January 2003 to 22 January 2003.

to understand the phenomenon of pollution. The winter concentrations of monoterpenes were unexpectedly high and in the ppbv range. They can be explained mainly by the much longer atmospheric lifetime of monoterpenes in winter, by the weather conditions, by the dynamics of the valley and by anthropogenic sources, specifically, wood combustion. This source was highlighted by a correlation between temperature and terpene concentrations, showing that the lower the temperature, the greater the terpene concentration. Effectively, the colder the weather, the more the population will heat itself. Moreover, modelling made it possible to demonstrate the effect of heating in the Chamonix measurement site with $20 \%$ in the concentration of VOC global concentration. The emission inven- tory gave $7 \%$ in mass of VOC total emissions for the whole valley at this period for heating. Consequently, the heating by wood burning is an important source of VOC emission in the urban area of Chamonix and must be taken into account for analysis and modelling, especially in winter at the time of VOC studies. Due to the formation of secondary aerosol by terpenes, correlations of aerosols to monoterpenes measurements will be performed in future work with modelling development.

\section{Acknowledgements}

The POVA program is supported in France by the Rhône Alpes Région, ADEME (Agence de l'Environnement et de la Maîtrise de l'Energie), METL (Ministère de l'Equipement, des Transports et du Logement), MEDD (Ministère de l'Ecologie et du Développement Durable), and Primequal 2. We are grateful for the input from our colleagues, in particular, Mr. Eric Chaxel and Pr. Francis Mc Cluskey.

\section{References}

Anquetin, S., Guilbaud, C., Chollet, J.P., 1999. Thermal valley inversion impact on the dispersion of a passive pollutant in a complex mountainous area. Atmospheric Environment 33, 3953-3959.

Atkinson, R., 2000. Atmospheric chemistry of VOCs and $\mathrm{NO}_{x}$. Atmospheric Environment 34, 2063-2101.

Brulfert, G., Chemel, C., Chaxel, E., Chollet, J.P., 2005 a. Modelling photochemistry in Alpine valleys. Atmospheric Chemistry and Physics 5 (2), 1797-1828.

Brulfert, G., Chollet, J.P., Jouve, B., Villard, H., 2005b. Atmospheric emission inventory of the Maurienne valley for an atmospheric numerical model. Science of the Total Environment 349 (1-3), 232-248.

Ciccioli, P., Brancaleoni, E., Cecinato, A., Sparapani, R., 1993. Identification and determination of biogenic and anthropogenic volatile organic compounds in forest areas of Northern and Southern Europe and a remote site of the Himalaya region by high-resolution gas chromatography-mass spectrometry. Journal of Chromatography A 643, 55-69.

Colomb, A., 2002. Les composes organiques volatils dans les vallées alpines: sources, évolutions et transformations. Ph.D. Thesis, University of Joseph Fourier, France.

Fontaine, H., 2000. Les composés organiques volatils dans les gaz d'échappement des automobiles: établissement de profils d'émission représentatifs de différentes conditions de conduite. Ph.D. Thesis, Ecole des Mines de Douai, France.

Fraser, M.P., Kleeman, M.J., Schauer, J.J., Cass, G.R., 2000. Modelling the atmospheric concentration of individual gasphase and particulate-phase organic compound. Environmental Science and Technology 34, 1302-1312. 
Goldan, P.D., Kuster, W.C., Fehsenfed, F.C., 1995. Hydrocarbon measurements in the southeastern United States: the rural oxidants in the southern environment (ROSE) program 1990. Journal of Geophysical Research 100, 25,945-25,963.

Guenther, A., Hewitt, C.N., Erickson, D., Fall, R., Geron, C., Graedel, T., Harley, P., Klinger, L., Lerdau, M., McKay, W.A., Pierce, T., Scholes, B., Steinbrecher, R., Tallamraju, R., Taylor, J., Zimmerman, P., 1995. A global model of natural volatile organic compound emissions. Journal of Geophysical Research 100, 8873-8892.

Hakola, H., Tarvainen, V., Laurila, T., Hiltunen, V., Hellen, H., Keronen, P., 2003. Seasonal variation of VOC concentrations above a boreal coniferous forest. Atmospheric Environment 37, 1623-1634.

Jenkin, M.E., Clemitshaw, K.C., 2000. Ozone and other secondary photochemical pollutants: chemical processes governing their formation in the planetary boundary layer. Atmospheric Environment 34, 2499-2527.

Kim, J.C., Kim, K.J., Kim, D.S., Han, S.H., 2005. Seasonal variations of monoterpene emissions from coniferous trees of different ages in Korea. Chemosphere 59, 1685-1696.

Lehning, M., Richner, H., Kok, G.L., 1996. Pollutant transport over complex terrain: flux and budget calculations fort he POLLUMET field compaign. Atmospheric Environment 30, 3027-3044.

Lobert, J.M., Scharffe, D.H., Hao, W.-M., Kuhilbusch, T.A., Seuwen, R., Warneck, P., Crutzen, P.J., 1991. Experimental evaluation of biomass burning emissions: nitrogen and carbon containing compounds. In: Levine, J.S. (Ed.), Global Biomass Burning: Atmospheric, Climatic, and Biospheric Implications. MIT Press, Cambridge, MA, USA, pp. 289-304.

Olivier, J.G.J., Bouwman, A.F., Van der Maas, C.W.M., Berdowski, J.J.M., Veldt, C., Bloos, J.P.J., Visschedijk, A.J.H., Zandveld, P.Y.J., Haverlag, J.L., 1996. Description of EDGAR Version 2.0: a set of global emission inventories of greenhouse gases and ozone-depleting substances for all anthropogenic and most natural sources on a per country basis and on 1 oxlo grid. National Institute of Public Health and the Environment (RIVM), Report No. 771060 002/TNOMEP Report No. R96/119, Bilthoven, Netherlands, 170pp.

Pio, C.A., Valente, A.A., 1998. Atmospheric fluxes and concentrations of monoterpenes in resin-tapped pine forests. Atmospheric Environment 32, 683-691.

Prévôt, A.S.H., Dommen, J., Baumle, J., Furger, M., 2000 Diurnal variations of volatile organic compounds and local circulation systems in a Alpine valley. Atmospheric Environment 34, 1413-1423.

Rouvière, A., Brulfert, G., Chemel, C., Jacob, V., Baussand, P., Chollet, J.P., 2004. Volatile organic compounds in the atmosphere of deep narrow alpine valleys: measurement and numerical modelling. Ninth FECS Conference on Chemistry and the Environment, Second SFC Meeting on Environmental Chemistry, Bordeaux, France, 29/08/04-01/09/04. http://magnet.lptc.u-bordeaux.fr/DCE9/.

Schauer, J.J., Kleeman, M.J., Cass, G.R., Simoneit, B.R.T., 2001. Measurement of emissions from air pollution sources, 3. C1-C29 organic compounds from fireplace combustion of wood. Environmental Science and Technology 35, 1716-1728.

Schauer, J.J., Kleeman, M.J., Cass, G.R., Simoneit, B.R.T., 2002. Measurement of emissions from air pollution sources, 5. C1-C32 organic compounds from gasoline-powered motor vehicles. Environmental Science and Technology 36, 3806-3814.

Staudt, M., Bertin, N., Hansen, U., Seufert, G., Ciccioli, P., Foster, P., Frenzel, B., Fugit, J.L., 1997. Seasonal and diurnal patterns of monoterpene emissions from Pinus pinea (L.) under field conditions. Atmospheric Environment 31 (Suppl. 1), 145-156.

Went, F.W., 1960. Blue hases in the atmosphere. Nature 187 , 641-643.

Wotawa, G., Kromp-Kolb, H., 2000. The research project VOTALP - general objectives and main results. Atmospheric Environment 34, 1319-1322. 